\title{
Gastrostomy Site
}

National Cancer Institute

\section{Source}

National Cancer Institute. Gastrostomy Site. NCI Thesaurus. Code C122646.

A surgically created external opening into the stomach. 